\title{
Hubungan Peran Orang Tua dengan Inisiasi Seks Pranikah pada Remaja di Prodi S1 Farmasi Universitas Muhammadiyah Kalimantan Timur
}

\section{The relationship between the Role of Parents and the initiation of premarital sex in Adolescents in the Pharmacy Study Program, Muhammadiyah University of East Kalimantan}

\author{
Yuliani winarti ${ }^{*}$, Wahyu Agung Budi Alamsyah ${ }^{1}$ \\ ${ }^{1}$ Prodi S1 Kesehatan Masyarakat, Universitas Muhammadiyah Kalimantan Timur, \\ Indonesia \\ *Korespondensi penulis: yw399@umkt.ac.id
}

Penyerahan: 18-08-2020, Perbaikan: 24-08-2020, Diterima: 22-09-2020

\begin{abstract}
The behavior of the initiation of premarital sex in adolescents is very worrying. According to data from the Komisi Penanggulangan AIDS (KPA) in 2019 in Samarinda City, the incidence of premarital sex with the highest impact of HIV / AIDS transmission in Samarinda Ulu District was 62\%, Samarinda Ilir 56\%, and Samarinda Utara 37\%, with a total of 375 people. They were affected by HIV/ AIDS. The role of parents in preventing premarital sexual behavior has a critical position. This study aims to analyze the relationship between the role of parents and the behavior of premarital sex initiation in adolescents in the Pharmacy Study Program, Muhammadiyah University of East Kalimantan. The research method used a cross-sectional design using the Chi-Square test. The sampling technique used stratified random sampling. The results showed a significant relationship between the role of parents and premarital sex behavior, with a $p$-value $<0.001$.
\end{abstract}

Keywords: the role of parents, the initiation of premarital sex.

\begin{abstract}
ABSTRAK
Perilaku inisiasi seks pranikah pada remaja sudah sangat mengkhawatirkan. Menurut data Komisi Penanggulangan AIDS (KPA) pada tahun 2019 di Kota Samarinda kejadian seks pranikah dengan dampak penularan penyakit HIV/AIDS tertinggi di Kecamatan Samarinda Ulu sebesar 62\%, Samarinda Ilir 56\%, dan Samarinda Utara 37\%, dengan jumlah keseluruhan sebesar 375 jiwa terdampak HIV/AIDS. Peran orang tua dalam mencegah perilaku seks pranikah memiliki posisi yang sangat penting. Penelitian ini bertujuan untuk menganalisis hubungan peran orang tua dengan perilaku inisiasi seks pranikah pada remaja di prodi S1 Farmasi Universitas Muhammadiyah Kalimantan Timur. Metode penelitian menggunakan rancangan cross sectional menggunakan uji Chi-Square. Tekhnik pengambilan sampel menggunakan stratified random sampling. Hasil penelitian menunjukkan adanya hubungan yang signifikan antara peran orang tua dengan perilaku seks pranikah, dengan nilai $p$-value $<0,001$.
\end{abstract}

Kata kunci: Inisiasi seks pranikah, Peran orang tua.

Jurnal Dunia Kesmas, Vol. 9 No. 3, Juli 2020, hal. 355-364 


\section{PENDAHULUAN}

Perilaku inisiasi seks pranikah di Kalimantan Timur sudah sangat mengkhawatirkan orang tua. Menurut Martunis dkk (2018) peran serta pola asuh pada orang tua memiliki peran yang penting dalam perilaku seks pranikah terhadap remaja, penelitian ini menjelaskan bahwa gambaran dampak dari peran serta pola asuh pada orang tua yang menganut peran dan pola asuh secara permisif atau memberikan larang cenderung memberikan kebebasan terhadap perilaku berpacaran.

Pada penelitian yang di kembangkan oleh Suwarni serta Selviana (2015) perilaku seks pranikah terhadap 300 remaja yang berada di 6 kecamatan kota Pontianak telah menunjukkan bahwa inisiasi seks pada remaja dimulai dengan berpegangan tangan $(82.7 \%)$, berpelukan $(60.7 \%)$, cium pipi $(66 \%)$, meraba pada daerah sensitif(19.3\%), seks oral $(7 \%)$, seks melalui anal (4\%), dan intercourse (14.7\%).

Menurut penelitian fajar dkk (2019) $(62.7 \%)$ orang tua memiliki pemikiran serta keyakinan yang baik tentang pentingnya peran orang tua dalam mencegah seks sedini mungkin, tetapi dengan presentase $(41.3 \%)$ masih menunujukkan perilaku yang buruk pada pencegahan seks pranikah, orang tua memberikan fasilitas telepon genggam, laptop, internet dirumah, uang, sepeda motor, mobil, yang dapat diakses dan terjangkaunya konten-konten negatif seksual yang dapat menyebabkan kemudahan remaja inisiasi seks pranikah.

Perubahan zaman telah membuat kemajuan dibidang transportasi dan telekomunikasi yang sudah menyebar secara meluas di dalam budaya remaja yang menyebabkan banyaknya perubahan terhadap masa remaja. Remaja mengalami perubahan secara signifikan dari moralitas, pemikiran serta pola perilaku remaja, hal ini disebabkan telah dipengaruhi oleh budaya luar atau barat yang membawa kebebasan dan informasi yang terbuka sehingga dapat memberikan kesempatan untuk melakukan perilaku negatif dalam kesehatan reproduksi. Kenakalan pada remaja merupakan fenomena yang mendunia sehingga sangat mempengaruhi proses perkembangan anak dan perhatian yang signifikan untuk masyarakat seperti tindak kejahatan, merokok, minum-minuman keras, dan berperilaku seks bebas. Seks Pranikah merupakan bentuk tindakan bermacam-macam dari rasa penasaran yang tinggi, berkencan, bercumbu, dan bersenggama. . Seks Pranikah adalah suatu tindakan dari bermacam-macam rasa ingin tahu yang tinggi, berkencan, bercumbu, dan berhubungan badan. Akibat dari akibat seks pranikah adalah terjadinya penyakit menular seksual (PMS), HIV atau AIDS dan kehamilan yang tidak diinginkan (KTD) yang berakhir dengan penguguran janin. Dan perilaku seks pranikah dimulai dari berbagai tantangan individu dan dari lingkungannya. (Kemenkes, 2018).

Berdasarkan data World Health Organization (WHO) pada tahun 2018 menunjukkan bahwa kasus dampak penyakit menular seksual yaitu HIV (Human Immunodeficiency Virus) tertinggi di Negara Lesotho 
dengan presentase $12.68 \%$ sedangkan untuk Negara Indonesia kasus dampak penyakit HIV 0.19\%.

Hasil survey kesehatan berbasis sekolah di Indonesia dalam Kemenkes (2018) menunjukkan gambaran faktor-faktor beresiko pada remaja pada usia 11-20 tahun adalah berperilaku seksual dengan presentase $(8.26 \%)$ pada remaja laki-laki dan dengan presentase $(4.17 \%)$ pada remaja perempuan yang pernah melakukan hubungan seksual.

Menurut data Komisi Penanggulangan AIDS (KPA) pada tahun 2019 di Kota Samarinda kejadian seks pranikah dengan dampak penularan penyakit HIV/AIDS tertinggi di Kecamatan Samarinda Ulu sebesar 62\%, Samarinda Ilir 56\%, dan Samarinda Utara 37\%, dengan jumlah keseluruhan sebesar 375 jiwa terdampak HIV/AIDS, terbesar berada di samarinda ulu.

Remaja yang mengalami jatuh cinta terhadap pasangannya rela melakukan apapun termasuk perilaku inisiasi seks pranikah. Hal ini di karenakan kurangnya pengawasan dan informasi tentang seksual dan kesehatan reproduksi secara intens oleh guru, orang tua, dan pelayanan kesehatan di sekolah (Abigail \& Carol, 2018).

\section{METODE}

Penelitian menggunakan penelitian secara kuantitatif dengan pendekatan penelitian cross sectional atau potong lintang. Populasi penelitian ini seluruh Mahasiswa/I di Program Studi S1 Farmasi Universitas Muhammadiyah Kalimantan Timur berjumlah 295 Mahasiswa/I dan perhitungan secara stratified random sampling didapatkan jumlah sampel sebesar
74 responden. Responden ini telah termasuk dalam kriteria inklusi yaitu, Mahasiswa/I Tingkat I, II, dan III di Universitas Muhammadiyah Kalimantan Timur. Sumber data penelitian yaitu data yang diperoleh langsung dari sumbernya dan data yang diperoleh pihak kedua serta sumber literatur.

Pengumpulan data penelitian menggunakan instrumen kuesioner pada kedua variabel yaitu peran orang tua dan perilaku inisiasi seks pranikah, dengan pilihan jawaban Ya/Tidak, menggunakan skala Guttman dengan teknik kolerasi Point-biserial untuk menunjukkan item skor butir-butir pertanyaan. Uji validitas dilakukan pada 22 responden diambil sebanyak 30\% dari total sampel 74 responden.

Hasil uji Validitas untuk Skala Guttman dengan metode koefisien Point Biserial pada variabel independen (peran orang tua) tidak ditemukannya pertanyaan yang tidak valid dan pada variabel dependen (inisiasi sesk pranikah) juga tidak ditemukan pertanyaan yang tidak valid. Reliabilitas untuk Skala Guttman dengan metode koefisien Kuder-Richardson

(KR-20)

didapatkan $a=0,920$ pada variabel peran orang tua dan $a=0,926$ pada variabel inisiasi seks pranikah. Kriteria pengujian reliabilitas dikatakan reliabel adalah jika nilai KR-20 atau KR-21 $\geq 0.70$ (Arikunto, 2006).

Variabel independen peran orang tua terdiri dari 2 kategori yaitu peran orang tua baik diberi skor (>5) sedangkan peran orang tua tidak baik diberi skor $(<5)$ serta variabel dependen tentang inisiasi seks pranikah terdiri 2 kategori yaitu ringan (pacaran, berkencan, berpegangan tangan, berpelukan, berciuman kening/pipi) dan berat 
(berpacaran, berkencan, berciuman basah, meraba, menggesekkan alat kelamin, oral seks, dan berhubungan seksual).

Uji statistik yang digunakan adalah Uji Chi Square dan memenuhi syarat dengan menggunakan uji Continuity Correction. Setelah dilaksankannya uji Continuity Correction, pengujian hipotesis berdasarkan taraf siginifikansi $5 \% \quad \mathrm{p}$-value $=0.05$ dengan data kategorik atau kuantitatif (ordinal, nominal).

\section{HASIL}

Hasil Analisis Univariat karakteristik Responden (Usia, Jenis Kelamin, Tinggal Bersama Orang Tua, dan Usia Mulai Pacaran) dapat dilihat pada Tabel 1.

\begin{tabular}{lcc}
$\begin{array}{l}\text { Tabel 1. Distribusi Karakteristik } \\
\text { Responden }\end{array}$ \\
\hline \multicolumn{1}{|c}{ Kategori } & Jumlah & $\begin{array}{c}\text { Presentase } \\
(\%)\end{array}$ \\
\hline Usia (Tahun) & & \\
18 & 20 & 27.0 \\
19 & 25 & 33.8 \\
20 & 29 & 39.2 \\
\hline Jenis Kelamin & & \\
Laki-laki & 25 & 33.8 \\
Perempuan & 49 & 66.2 \\
\hline Tinggal Bersama Orang tua \\
Ya & 31 & 41.9 \\
Tidak & 43 & 58.1 \\
\hline Usia Mulai Pacaran (Tahun) \\
11 & 5 & 6.8 \\
12 & 17 & 23.0 \\
13 & 16 & 21.6 \\
14 & 14 & 18.9 \\
15 & 19 & 25.7 \\
Tidak Pernah & 3 & 4.1 \\
\hline
\end{tabular}

Pada tabel 1 menjelaskan bahwa pada kategori usia responden terbanyak pada kategori usia remaja akhir 20 tahun sebesar 29 orang dengan presentase (39.2\%). jenis kelamin didominasi oleh perempuan sebesar49 responden (66.2\%). untuk kategori status tempat tinggalsebagian besar tidak tinggal bersama orang tua dikarenakan responden banyak dari daerah yang study di ibu kota sebesar 43 (58.1\%) sedangkan sisanya 31 (41.9\%) tinggak bersama orang tua karena memang warga Samarinda. Kategori usia mulai berpacaran dari 74 responden usia termudan berpacaran pada usia 11 tahun sebayak 5 (6.8\%) kemudian usia 12 tahun 17 $(23.0 \%), 13$ tahun sebanyak 16 $(21.6 \%), 14$ tahun sebanyak 14 $(18.9 \%)$, usia 15 tahun sebanyak 19 $(25.7 \%)$ dan yang tidak pernah pacaran 3 orang (4.1\%).

\section{Tabel 2. Distribusi frekuensi peran orang tua dan perilaku inisiasi seks pranikah}

\begin{tabular}{lcc}
\hline \multicolumn{1}{c}{ Variabel } & n & $\begin{array}{c}\text { Presentase } \\
(\mathbf{\%})\end{array}$ \\
\hline Peran Orang Tua & & \\
Baik & 41 & 55.4 \\
kurang & 33 & 44.6 \\
\hline $\begin{array}{l}\text { Perilaku Inisiasi } \\
\text { Seks Pranikah }\end{array}$ & & \\
$\begin{array}{l}\text { Ringan } \\
\text { Berat }\end{array}$ & 38 & 51.4 \\
\hline
\end{tabular}

Berdasarkan hasil pada tabel 2 menunjukkan peran orang tua terkait inisiasi seks pranikah terdapat dua kategori yaitu baik dan kurang. Sebanyak 41 responden dengan presentase (55.4\%) termasuk pada kategori baik dalam hal peran orang tua dalam memberikan Informasi tentang reproduksi, bimbingan, serta pengawasan pada remaja dan dari 74 responden sebesar 33 (44.6\%) responden memiliki peran orang tua dalam kategori kurang dalam memberikan informasi tentang kesehatan reproduksi, bimbingan, serta pengawasan pada anak remajanya. Dan selanjutnya pada 
variabel inisiasi seks pranikah terdapat dua kategori yaitu ringan dan berat. Sebanyak 38 responden dengan presentase (51.4\%) memiliki perilaku inisiasi seks pranikah kategori ringan sedangkan 36 responden dengan presentase $(48.6 \%)$ berperilaku inisiasi seks pranikah dengan kategori berat.

Tabel 3. Peran Orang Tua dengan Inisiasi Seks Pranikah di Program Studi S1 Farmasi Universitas Muhammadiyah Kalimantan Timur

\begin{tabular}{lccccc}
\hline $\begin{array}{c}\text { Peran Orang } \\
\text { Tua }\end{array}$ & \multicolumn{2}{c}{ Inisiasi Seks Pranikah } & n & $\begin{array}{c}\text { p- } \\
\text { value }\end{array}$ & $\begin{array}{c}\text { OR } \\
\text { (CI 95\%) }\end{array}$ \\
\cline { 2 - 3 } Ringan & Berat & & $41(55.4 \%)$ & $<0.001$ & 0.111 \\
Bidak baik & $12(29.3 \%)$ & $29(70.7 \%)$ & $41.35)$ & & $(0.038-0.325)$ \\
\hline
\end{tabular}

Hasil tabel 3 menunjukkan hasil Uji Continuity Corection yang sudah dilakukan telah diperoleh nilai $p$ value sebesar $<0.001$, dimana nilai tersebut lebih kecil dari taraf siginifikan a sebesar 0.05, dapat disimpulkan bahwa terdapat hubungan antara peran orang tua dengan perilaku inisiasi seks pranikah pada remaja di Program Studi S1 Farmasi Universitas Muhammadiyah Kalimantan Timur.

Nilai OR (Odss Ratio)
menunjukkan hasil yaitu 0.111 yang diartikan peran orang tua yang baik berpeluang 0.111 kali untuk pencegahan perilaku inisiasi seks pranikah pada remaja dibandingkan dengan peran orang tua yang kurang. Nilai pada CI (Confidence Interval 95\%) yaitu (0.038-0.325), hasil ini menunjukkan bahwa nilai $\mathrm{CI}<1$ sehingga hasil protektif atau bisa dikatakan terdapat sifat pencegahan perilaku inisiasi seks pranikah pada remaja di Program Studi S1 Farmasi Universitas Muhammadiyah Kalimantan Timur jika orang tua berperan baik dalam pola pengasuhan dan pengawasan anaknya.

\section{PEMBAHASAN}

Menurut BKKBN (2012) remaja dibagi menjadi remaja awal pada usia (11-13) Tahun, remaja menengah pada usia (14-16) Tahun, dan remaja akhir pada usia (17-20), dalam hasil pada tabel 1 remaja didominasi oleh remaja dalam kategori remaja akhir dimana pada fase ini telah menuju ke fase dewasa, secara sosial ekonomi remaja mulai mandiri hingga berkembang ke arah yang lebih kongkret yaitu kebutuhan operasional.

Berdasarkan hasil penelitian menunjukkan responden dengan kategori jenis kelamin terbanyak adalah perempuan sebanyak 49 orang dengan presentase (66.2\%) dan berjenis kelamin laki-laki sebanyak 25 orang dengan presentase (33.8\%). Menurut Mualifah Tahun (2019) di Kelurahan Bumijo Jetis Yogyakarta jenis kelamin tidak memiliki pengaruh untuk melakukan seks pranikah tetapi justru kecenderungan yang mempengaruhi lebih besar berada pada laki-laki dalam melakukan seks pranikah dibandingkan dengan remaja wanita sebesar 1.356 kali.

Pada tabel 1 menunjukkan kategori tinggal bersama orang tua dari 74 responden sebanyak 43 orang tidak tinggal bersama orang tua dengan presentase (58.1\%). Dari penelitian Asmara pada tahun (2016) di Kos "Las Vegas" sebesar 80 responden remaja tidak tinggal bersama orang tuanya memiliki perilaku seks bebas sangat tinggi hal ini karena kurangnya pantauan pada remaja 
dan mempunyai resiko besar di masa dewasa nanti akan melanggar norma-norma masyarakat.

Kategori usia mulai berpacaran yaitu pada usia 15 tahun sebanyak 19 orang dengan presentase (25.7\%) dan yang terendah adalah usia 16 tahun sebanyak 3 orang dengan presentase $(4.1 \%)$. Untuk kategori usia termuda mulai berpacaran dari 74 responden usia 11 tahun sebanyak 5 orang dengan presentase $(6.8 \%)$ dan usia tertua mulai berpacaran berumur 16 tahun sebanyak 3 orang dengan presentase (4.1\%). Hasil penelitian Mualifah pada tahun (2019) di Kelurahan Bumijo Jetis Yogyakarta tahap umur (12-15) tahun memiliki pacar sebanyak (41.11\%) dan sebanyak (20.58\%) pada umur (9-11) tahun memiliki pacar, dimulainya seks pranikah pada remaja dapat dilihat dari besarnya responden memiliki pacar, karena memiliki pasangan salah satu pemicu terjadinya perilaku seks pada remaja.

pada tabel 2 menunjukkan peran orang tua pada perilaku inisiasi seks pranikah sebesar 41(55.4\%) responden termasuk pada kategori baik. Peran orang tua dalam hal ini sangat mempengaruhi apakah anak remaja berperilaku seks pranikah atau tidak, penelitian ini sejalan dengan penelitian yang dilakukan oleh Mariani dkk pada Tahun (2018) di SMAN 1 Jamblang Cirebon dengan hasil bahwa peran orang tua yang baik melakukan tindakan pengawasan, dan interaksi dengan presentase (62.9\%), dalam penelitian ini juga dikemukakan bahwa pentingnya tindakan pengawasan dan interaksi terhadap remaja dapat menunda bahkan menghindari terjadinya perilaku seks bebas pada remaja. Begitu juga sebaliknya jika peran orang tua kurang dalam memberikan Informasi tentang reproduksi, bimbingan, serta pengawasan tentang kesehatan reproduksi pada anak remajanya maka kecenderungan untuk berperilaku inisiasi seks pranikah akan lebih besar. Konsep diri anak sesungguhnya dipengaruhi oleh orang tua, teman sebaya dan lingkungannya. Orang tua, teman sebaya dan lingkungan memberikan peluang untuk anak bisa berinteraksi dengan orang-orang yang baru dikenal, dengan demikian pentingnya peran orang tua yang harus berusaha mengenalkan anaknya terhadap lingkungan sosialnya dan teman sebayanya dengan menerapkan aturan-aturan seperti memberikan pengawasan serta komunikasi yang dapat meminimalisir terjadinya resiko perilaku seksual yang tinggi (Agustiani, 2016). Hal ini juga didukung oleh penelitian Achille dkk pada tahun (2017) di Benin yang menunjukkan bahwa dari total 576 ayah atau ibu yang terlibat dalam survey, secara keseluruhan didapatkan hasil $90.8 \%$ menyatakan bahwa pendidikan kesehatan reproduksi merupakan tugas orang tua, pendidikan seks pada remaja berperan penting dalam perkembangan moral anak. Tanpa adanya tindakan pengawasan secara serius dari orang tua dan komunikasi sehat dalam keluarga, maka remaja dapat jatuh pada perilaku yang buruk. Maka dari itu peran orang tua untuk memberikan pengawasan secara serius, memilih teman, mendidik, dan memberikan waktu senggang lebih untuk berkomunikasi dapat mencegah lebih dini terhadap anak yang ingin terjerumus perilaku buruk (Kusumaryani, 2017).

Pada tabel 3 menunjukkan dari hasil analisis bivariate dengan uji Continuity Correction didapatkan bahwa ada hubungan antara peran orang tua dengan inisiasi seks pranikah pada remaja di Program 
Studi S1 Farmasi Universitas Muhammadiyah Kalimantan Timur. Uji ini digunakan karena uji chi square memenuhi syarat. Syarat yang terpenuhi pada uji chi square adalah adanya sel yang memenuhi niali frekuensi harapan. Kesimpulan ini bisa digunakan karena hasil perhitungan, bahwa nilai pvalue $<0.001$ lebih kecil dari taraf siginifikan a yaitu 0.05 sehingga terdapat hubungan peran orang tua dengan inisiasi seks pranikah pada remaja di Program Studi S1 Farmasi Universitas Muhammadiyah Kalimantan Timur. Hal ini sejalan dengan penelitian yang dilakukan Ulfah pada Tahun (2015) di SMKN 1 Sedayu bahwa peran orang tua terhadap perilaku inisiasi seks pranikah memiliki hubungan secara signifikan dengan p-value $<0.001$. Menurut Motsomi pada tahun (2016) di Afrika Selatan menunjukkan bahwa sebesar $70 \%$ perilaku inisiasi seks pranikah terjadi karena kurangnya Komunikasi antara orang tua dan remaja mengenai seksualitas. Hal ini juga di dukung oleh penelitian Widman dkk pada Tahun (2016) di Amerika serikat yang menunjukkan bahwa perilaku seksual berisiko di kalangan pemuda AS adalah masalah yang serius. Hal lain yang mempengaruhi remaja melakukan inisasi seks pranikah adalah lingkungan. Lingkungan mengajarkan remaja bagaimana berinteraksi, pola kehidupan beragama, dan mempelajari nilai moral serta sikap individu (Ulfah, 2018).

Inisiasi seks pranikah dibagi menjadi 2 kategori yaitu ringan (termasuk menaksir, pergi berkencan, mengkhayal, berpegangan tangan, berciuman ringan). Sejalan dengan penelitian Setiawan dan Winarti pada tahun (2019) bahwa besarnya perilaku seks pranikah pada kategori berat $96 \%$ termasuk dalam hal ini berciuman bibir atau mulut dan lidah, meraba, menempelkan alat kelamin, oral seks, berhubungan seksual. Seorang remaja dengan penasaran yang tinggi selalu ingin mencoba hal yang belum mereka lakukan dan mereka ingin mengetahui tentang seks pranikah, hal ini dipengaruhi kurangnya pengetahuan, pemahaman agama, sumber informasi, dan peran keluarga (Elvi \& Ratna, 2015).

Remaja merupakan seperempat dari populasi yang aktif secara seksual dan dampak lain dari perilaku inisiasi seks pranikah ini adalah meningkatnya penyakit infeksi menular seksual (IMS) pada remaja yang telah mencapai 9 juta jiwa, termasuk lebih dari 8.300 kasus baru HIV setiap tahun yang diderita oleh remaja. Menurut data Pusdatin (Pusat Data dan Informasi) pada tahun 2017 menunjukkan bahwa kasus dampak penyakit menular seksual yaitu HIV (Human Immunodeficiency Virus) untuk Negara Indonesia sudah mencapai $0.48 \%$ dengan gender terbanyak adalah pria dengan presentase $(62 \%)$ serta perempuan dengan presentase $(38 \%)$ dan untuk kategori umur 15-19 tahun sebanyak 1.729 jiwa. Masalah penyakit menular seksual HIV (Human Immunodeficiency Virus) sudah menjadi masalah darurat global karena hampir diseluruh dunia sebanyak 35 juta orang hidup berdampingan dengan HIV (Human Immunodeficiency Virus) dan penyumbang terbesar penyakit ini menyebar dengan masif salah satunya melalui perilaku seks pranikah pada remaja.

\section{KESIMPULAN}

Kategori usia didominasi usia remaja akhir, yaitu usia 20 tahun sebesar 29 orang dengan presentase (39.2\%). 
jenis kelamin didominasi oleh perempuan sebesar 49 responden $(66.2 \%)$. Untuk kategori status tempat tinggal sebagian besar tidak tinggal bersama orang tua sebesar $43(58.1 \%)$. Kategori usia mulai berpacaran dari 74 responden usia termuda berpacaran pada usia 11 tahun sebayak $5(6.8 \%)$ dan yang tidak pernah pacaran 3 orang $(4.1 \%)$. hasil analisis hubungan peran orang tua dengan perilaku inisiasi seks pranikah pada remaja menunjukkan hasil yang signifikan dengan nilai $p$-value $<0.001$. hal ini menunjukkan bahwa ada hubungan antara peran orang tua dengan perilaku inisiasi seks pranikah pada remaja prodi S1 Farmasi Universitas Muhammadiyah Kalimantan Timur.

\section{SARAN}

Berdasarkan hasil penelitian ini maka dapat dibuat saran bagi Program Studi S1 Farmasi Universitas Muhammmadiyah Kalimantan Timur yaitu komunikasi dengan orang tua perlu ditingkatkan dalam hal melibatkan orang tua secara aktif dalam proses pengawasan pada anak-anaknya. Untuk pihak universitas mengaktifkan kembali UKM sebagai unit kegiatan mahasiswa sehingga tersedianya fasilitas tersebut dapat menstimulasi mahasiswa untuk aktif dalam kegiatan kemahasiswaan dan membantu mahasiswa/I terhindar dari inisiasi seks pranikah.

\section{DAFTAR PUSTAKA}

Abigail, E.MD. Carol, A.F.MD. (2018). Adolescent Health, Confidentiality in Healthcare, and Communication with Parents. The Journals of Pediatrics,199,(https://www.jped s.com/article/S0022- 3476(18)30583-3/fulltext, diperoleh 20 Februari 2020)

Achille, O. Tonato, B. Salifou, K. Hounkponou, A. Hounkpatin, B. Sidi, R. Vodouhe, M. Mevo, G. Perrin, R. (2015). Parents' Perceptions and Practices as Regards Adolescents' Sex Education in the Home Environment in the City of Come, Benin in 2015. Reproductive System \& Sexual Disorders: Current Research, 6(2), (https://www.longdom.org/openaccess/parents-perceptions-andpractices-as-regardsadolescents-sex-education-inthe-home-environment-in-thecity-of-come-benin-in-20152161-038X-1000209.pdf, diperoleh 22 April 2020)

Asmara, A.D. (2016). Faktor-faktor Yang Berhubungan Dengan Perilaku Seksual Pranikah Beresiko Kehamilan Tidak Diinginkan Pada Mahasiswa Yang Bertemapat Tinggal Di Kos "Las Vegas". Skripsi, tidak dipublikasikan, Semarang, Universitas Semarang

Arikunto, S. (2006). Prosuder Penelitian Suatu Pendekatan Praktek. Jakarta: PT Rineka Cipta

Darmawan, D. (2016). Metode Penelitian Kuantitatif. Bandung: PT Remaja Rosdakarya.

Fajar, N.A. Etrawati, F. Lionita, W. (2019). Determinan of Parents Role in Adolsecent Premarital Sex Behavior: An ApplicativeModel.JurnalMKMI,15( 2),(https://www.researchgate.ne t/publication/337345077_Determ inant_of_Parents_Role_in_Adoles cent_Premarital_Sex_Behavior_A n_Applicative_Model, diperoleh 20 Februari 2020).

Februanti, S. Alpiyanto, R. Kartilah, T. (2017). Gambaran 
Pengetahuan Remaja Tentang Dampak Seks Pranikah di Salah Satu SMA Kota Tasikmalaya. Jurnal Kesehatan Bakti Tunas Husada, $17(2)$, (https://ejurnal.stikesbth.ac.id/in dex.php/P3M_JKBTH/article/dow nload/252/220, diperoleh 15 April 2020).

Elvi, D. Dewi, R. (2015). FaktorFaktor Yang Berhubungan Dengan Perilaku Seksual Pranikah Pada Remaja SMP 1 Talang Empat Kabupaten Bengkulu Tengah, Jurnal Ikesma, 11(1), (

https://jurnal.unej.ac.id/index.ph p/IKESMA/article/view/4356/329 4, diperoleh 12 Maret 2020)

Kementrian Kesehatan. (2018). Rencana program pencegahan dan pengendalian penyakit 20152019 edisi revisi. Direktorat Jenderal Pencegahan dan Pengendalian Penyakit, (https://erenggar.kemkes.go.id/file2018/e -performance/1-465827-

3tahunan-024.pdf, diperoleh 29 Februari 2020)

Mariani, N.N. Murtadho, F.S. (2018). Peran Orang Tua, Pengaruh Teman Sebaya, Dan Sikap Berhubungan Dengan Perilaku Seksual Pranikah Pada SiswaSiswi SMA Negeri 1 Jamblang Kabupaten Cirebon. JurnalCare,6(2),(https://jurnal.u nitri.ac.id/index.php/care/article/ view/904, diperoleh 1 Juni 2020).

Martunis. (2017). Pengaruh Peran Serta Pola Asuh Orang Tua Terhadap Perilaku berpacaran. Jurnal Ilmiah Mahasiswa Bimbingan dan Konseling,3(2),(https://etd.unsyi ah.ac.id/index.php?p=show_deta il\&id=33181 diperoleh

Februari 2020)

Mualifah, L. Punjastuti, B. (2019). Gambaran Inisiasi Seks Pranikah Pada Remaja. Jurnal Kesehatan Karya Husada, 7(2) (http://jurnal.poltekkeskhjogja.a c.id/index.php/jkkh/article/view/ 233, diperoleh 22 Maret 2020).

Motsomi, K. Makanja, C. Basera, T. Nyasulu, P. (2016). Factors affecting effective communication about sexual and reproductive health issues between parents and adolescents in zandspruit informal settlement, Johannesburg, South Africa. Pan African Journal, 2(2), (https://pubmed.ncbi.nlm.nih.go v/28292083/, diperoleh 15 April)

Nisar, M. Uttah, S. Ali, M. (2015). Juvenile Delinquency: The Influence of Family, Peer, and Economic Factors on Juvenile Deliquencts, AppliedScienceReports,9(1),(http s://www.researchgate.net/public ation/290144049 Juvenile Delin quency_ , diperoleh 22 Maret 2020)

Notoatmodjo, S. (2010). Metodologi Penelitian Kesehatan. Jakarta: PT Rineka Cipta

Pangesti, S. D. Tianingrum, A. N. (2019). Hubungan Pola Asuh Orang Tua dengan Kenakalan Remaja Sekolah di Wilayah Kerja Puskesmas Harapan Baru. Borneo Student Research. 111 (4).

(http://journals.umkt.ac.id/index .php/bsr/article/view/416/305, diperoleh 11 Juli 2020)

Sarwono, S. W. (2011). Psikologi Remaja Edisi Revisi. Jakarta: PT Raja Grafindo Persada.

Setiawan, A. Winarti, Y, (2019). Hubungan Lingkungan Keluarga dengan Perilaku Inisiasi Seks 
Pranikah Pada Remaja di SMA Negeri 16 Samarinda. Borneo Student Research. 111 (3), (http://journals.umkt.ac.id/index .php/bsr/article/view/525/203, diperoleh 11 Juli 2020)

Suwarni, L. Selviana. (2015). Inisiasi Seks Pranikah Remaja dan Faktor yang mempengaruhi. Jurnal Kesehata Masyarakat, 10(2),

(https://journal.unnes.ac.id/nju/i ndex.php/kemas/article/view/33 78, diperoleh 18 Februari 2020). Kusumaryani, M. (2017). Brief Notes: Prioritaskan Kesehatan Reproduksi Remaja Untuk Menikmati Bonusi Demografi. Lembaga Demografi FEB UI, $1(6)$, (https://ejournal.ui.ac.id/index.p hp/jikmu/article/view/7463, diper oleh 22 Mei 2020).

Ulfah, M. (2018). Faktor-Faktor Yang Mempengaruhi Perilaku Seksual Pranikah Pada Remaja SMP dan SMA Eks-Kota Administratip Cilacap. Jurnal Ilmiah IImu-IImu Kesehatan, 16(3), (http://jurnalnasional.ump.ac.id/ index.php/medisains/article/view /3733, diperoleh 8 April 2020)

WHO. (2018). Monitoring Health for The SDG's. World Health Statistic, (https://apps.who.int/iris/bitstre am/handle/10665/272596/97892 41565585-eng.pdf, diperoleh 26 Februari 2020)

Widman, L. Choukas-Bradley, S. Noar, S. M. Nesi, J. Kyla, G. (2016). Parent-Adolescent Sexual Communication and Adolescent Safer Sex Behavior: A Meta-Analysis. JAMA Pediatr, 170 (1), (https://pubmed.ncbi.nlm.nih.go v/26524189/, diperoleh 2 Juni 2020). 